\title{
Competition Between Fisheries and Marine Mammals for Prey and Primary Production in the Pacific Ocean
}

\author{
Andrew W. Trites \\ Marine Mammal Research Unit, Fisheries Centre, University of British Columbia \\ 2204 Main Mall, Vancouver, British Columbia, Canada V6T 1 Z4 \\ and \\ Villy Christensen and Daniel Pauly ${ }^{1}$ \\ International Center for Living Aquatic Resources Management (ICLARM) \\ Manila, Philippines
}

\begin{abstract}
The degree of competition between fisheries and marine mammals in the Pacific Ocean was estimated for 7 statistical areas defined by the Food and Agriculture Organization of the United Nations (FAO). Catch statistics compiled from FAO sources show that the amount of fish caught in the Pacific Ocean rose from 2 million tons in the late-1940s to over 50 million tons in the early-1990s. Recent stagnation and declines occurring in some areas of the Pacific suggest that Pacific fisheries cannot continue to expand as they had previously.
\end{abstract}

Based on estimates of population size, total biomass and daily consumption rates, it was estimated that the 84 species of marine mammals inhabiting the Pacific Ocean consume about three times as much food as humans harvest. A large fraction $(>60 \%)$ of the food caught by marine mammals consisted of deep sea squids and very small deep sea fishes not harvestable by humans, thus limiting the extent of direct competition between fisheries and marine mammals. Moreover, the most important consumers of commercially exploited fish are other predatory fish, not marine mammals.

Although direct competition between fisheries and marine mammals for prey appears rather limited, there may be considerable indirect competition for primary production. The primary production required to sustain marine mammals in each of the 7 FAO areas varies within a narrow range, suggesting that the diversity and abundance of marine mammals may have slowly evolved to fully exploit their niche and maximize their use of available primary production. This contrasts with the rapid expansion of fisheries and their relatively recent dependence on primary production, which may have led to what we call 'food web competition'.

Key words: competition, fisheries, food/feeding, marine mammals, Pacific Ocean

\section{Introduction}

The Pacific Ocean ranges from the high Arctic in the north to the Antarctic continent in the south, and is the largest of the world's oceans with a surface area of nearly 180 million $\mathrm{km}^{2}$. It is rather homogeneous biogeographically, consisting largely of a central plate with a distinct and diverse load of co-evolved organisms and ecosystems. Eightyfour species of whales, dolphins, porpoises, seals and sea lions, totally over 20 million individuals, inhabit the Pacific Ocean - while over a billion people line its rim and draw upon its resources.

This study briefly explores the use and development of fishery resources in the Pacific Rim, and their relationship to marine mammals of the Pacific. The objective is to compare the fisheries catches of the early-1990s to the amount of food consumed by marine mammals, and to estimate the fraction of the primary production required to sustain the food web upon which the fisheries and the marine

${ }^{1}$ Present address: Fisheries Center, University of British Columbia, 2204 Main Mall, Vancouver, British Columbia, Canada V6T 1 Z4 
mammals depend. An attempt is also made to assess the extent of competition by estimating the overlap between marine mammal diets and fishery catches, and conclude with some implications of our findings for fisheries management and research.

\section{Methods}

\section{Catch}

The Food and Agriculture Organization of the United Nations (FAO) divided the world into 88 statistical regions, of which 7 are contained in the Pacific Ocean (Fig. 1, Table 1). The amounts of fish caught in each of these 7 regions over the period 1948 to 1992 were taken from the FAO FISHSTAT Database and from the FAO yearbook (FAO, 1994). Catches were compiled by FAO 'commodity' group (i.e. set of species with similar life history such as 'anadromous fishes', or habits such as 'small pelagics').

\section{Consumption}

Amounts of prey caught and consumed each day by marine mammals were estimated from

$$
Q_{i}=\sum_{s} N_{i, s} W_{i, s} R_{i, s}
$$

where $N_{i, s}$ is the number of individuals (all age classes) by sex $s$ of species $i$ in the Pacific Ocean; $W_{i, s}$ is the mean individual weight by sex and species; and $R_{i, s}$ is the daily ration for an individual of weight $W_{i, s}$.

Estimates of total population sizes $\left(N_{i, s}\right)$ and their distribution within the seven FAO areas are documented in Table 2. The proportion of marine mammals residing within the Pacific were estimated from distribution maps drawn by Reijnders et al. (1993) and Jefferson et al. (1993). Population estimates were largely drawn from Northridge (1984), Reijnders et al. (1993) and Jefferson et al. (1993) and appear to be reasonably accurate for pinnipeds, the great whales and some species of dolphins, but represent little more than educated 'order-of-magnitude' guesses for mid-sized cetaceans such as the beaked whales. When presented with 'order-of-magnitude' estimates (e.g. '00 000s), we conservatively chose a value that corresponds roughly to the geometric mean (i.e. 300000$)$ from the range of possible values (i.e. 100000 to 1000000 ). We assumed the proportion of females in the total population to be 0.5 for all species, except for sea lions and fur seals, for which a value of 0.6 was used (Trites and Pauly, 1997).

Sex specific mean weights $\left(W_{i, s}\right)$ for 13 species of pinnipeds and 17 species of cetaceans were calculated from the product of average weight-at-age (determined from published growth curves) and the relative numbers alive (predicted from life history tables scaled by longevity, as described in Barlow and Boveng, 1991). This resulted in biomass-at-age curves (Trites and Pauly, 1997). Individual weights below which $50 \%$ of the cumulative biomass occurred were defined as $W_{i, s}$. Mean weights of species with unknown growth curves were estimated from measures of maximum body length $\left(L_{i, s}\right)$ according to the relation

$$
W_{i, s}=a L_{i, s}^{b}
$$

The functional relationship was derived for species $i$ and sex $s$ with known growth curves, and was estimated separately for pinnipeds and cetaceans (Trites and Pauly, 1997).

An individual's daily consumption or ration $(\mathrm{kg}$ per day) was estimated for each species using

$$
R_{i, s}=0.1 W_{i, s}^{0.8}
$$

where $W_{i, s}$ is the mean body weight in $\mathrm{kg}, 0.8$ is from Equation 23 in Innes et al. (1987), and 0.1 is a downward adjusted value (from 0.123 in Innes et al. 1987) to account for the difference between ingestion for growth and ingestion for maintenance. Estimates of daily ration from Equation 3 range from $1.1 \%$ of body weight per day in a $50000 \mathrm{~kg}$ baleen whale (i.e. $574 \mathrm{~kg}$ per day), to $4.5 \%$ of body weight per day in a small $50 \mathrm{~kg}$ dolphin $(2.3 \mathrm{~kg}$ per day), and are compatible with present knowledge of the biology of large and small marine mammals (Bonner 1989).

The composition of the diet for each of the 84 species of marine mammals was derived from published accounts of stomach contents, as well as from morphological, behavioural and other information (Klinowska, 1991; Pauly et al., 1997). Diet composition was grouped by 8 types of food: benthic invertebrates, large zooplankton, small squids, large squids, small pelagic fishes, mesopelagic fishes, miscellaneous fishes and higher vertebrates (Table 3). 


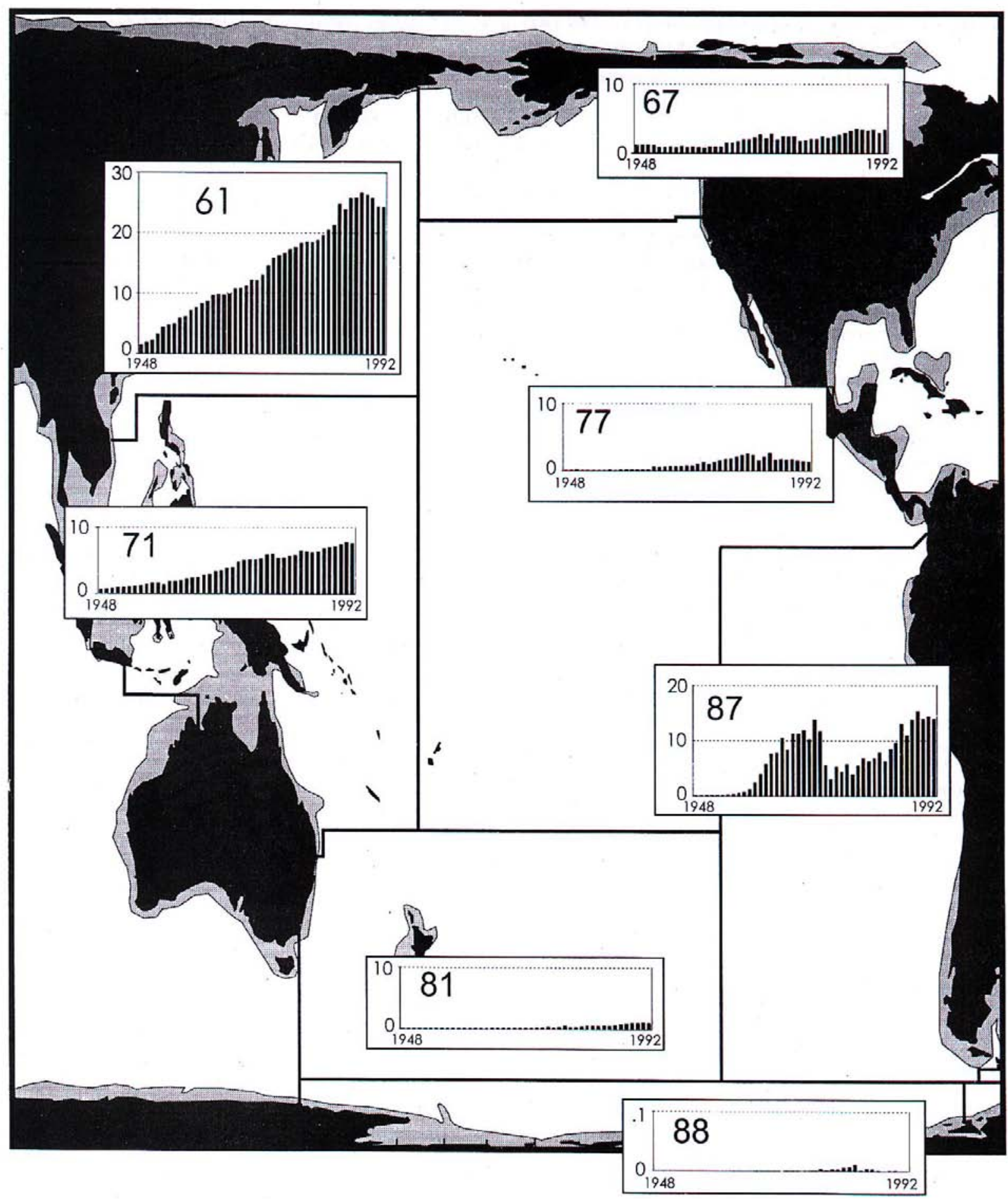

Fig. 1. Time series of Pacific ocean fisheries catches (tons $\times 10^{6}$ ) by FAO area for the period 1948 to 1992 . Note the stagnation or decline of catches in recent years. The projection (Peters 1983) allows direct comparisons of surface and shelve areas (shaded) from which the overwhelming bulk of the fisheries catches originate.

\section{Primary production}

The total amount of primary production in each of the seven FAO Pacific regions was derived from a global analysis by Longhurst et al. (1995), who divided the world's oceans into 56 'provinces', and estimated primary production for each from satellite 
TABLE 1. Key features of the seven areas used by FAO to report fisheries statistics, with 1992 catches (FAO 1994). Percentage estimates of shelf areas are approximate.

\begin{tabular}{|c|c|c|c|c|c|c|}
\hline $\begin{array}{l}\text { FAO } \\
\text { area }\end{array}$ & $\begin{array}{c}\text { Region } \\
\text { of the Pacific }\end{array}$ & Latitude & $\begin{array}{c}\text { Area } \\
\left(\mathrm{km}^{2} \times 10^{3}\right) \\
\text { and } \% \text { shelf }\end{array}$ & $\begin{array}{c}\text { Catch } \\
\text { in } 1992 \\
\left(\text { ton } \times 10^{3}\right)\end{array}$ & $\begin{array}{c}\text { By-catch }{ }^{a} \\
(\% \text { of catch })\end{array}$ & 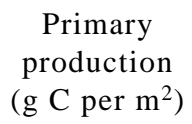 \\
\hline 61 & Northwest & $65^{\circ} \mathrm{N}-15^{\circ} \mathrm{N}$ & $20476 \quad(4.7)$ & 24199 & 39.8 & 215 \\
\hline 67 & Northeast & $65^{\circ} \mathrm{N}-40^{\circ} \mathrm{N}$ & $7503(12.9)$ & 3148 & 28.2 & 272 \\
\hline 71 & Western Central & $15^{\circ} \mathrm{N}-25^{\circ} \mathrm{S}$ & 33233 (13.9) & 7710 & 43.0 & 128 \\
\hline 77 & Eastern Central & $40^{\circ} \mathrm{N}-5^{\circ} \mathrm{N}$ & $48899 \quad(0.9)$ & 1342 & 49.9 & 98 \\
\hline 81 & Southwest & $30^{\circ} \mathrm{S}-50^{\circ} \mathrm{S}$ & 28375 & 1114 & 29.7 & 118 \\
\hline 87 & Southeast & $5^{\circ} \mathrm{N}-60^{\circ} \mathrm{S}$ & $30016 \quad(1.3)$ & 13899 & 18.5 & 120 \\
\hline 88 & Antarctic & $60^{\circ} \mathrm{N}-\left(75^{\circ} \mathrm{S}\right)$ & $10386(21.7)^{b}$ & $<1^{\mathrm{c}}$ & 29.5 & 147 \\
\hline All & Total Pacific Ocean & $65^{\circ} \mathrm{N}-\left(75^{\circ} \mathrm{S}\right)$ & 178888 & 51412 & 33.9 & 135 \\
\hline
\end{tabular}

a Adapted from Alverson et al. (1994).

b Approximate value.

c Consisting of 50 tons of krill (Euphausia superba) caught from 1 July 1991 to 30 June 1992.

TABLE 2. Global and Pacific population estimates for the 84 species of marine mammals inhabiting the Pacific Ocean during the 1980s and early 1990s. The proportions of animals within the Pacific and within each of the 7 Pacific FAO areas were estimated from range maps displaying the distribution of each species. Population estimates were largely drawn from Northridge (1984), Reijnders et al. (1993) and Jefferson et al. (1993). Order of magnitude estimates are indicated by an apostrophe (e.g. '000).

\begin{tabular}{|c|c|c|c|c|c|c|c|c|c|c|}
\hline \multirow[b]{2}{*}{$\begin{array}{l}\text { Species } \\
\text { common names }\end{array}$} & \multicolumn{3}{|c|}{ Proportion } & \multicolumn{7}{|c|}{ Proportion of Pacific population in each FAO area } \\
\hline & $\begin{array}{c}\text { World } \\
\text { population }\end{array}$ & $\begin{array}{c}\text { in } \\
\text { Pacific }\end{array}$ & $\begin{array}{c}\text { Pacific } \\
\text { population }\end{array}$ & 61 & 67 & 71 & 77 & 81 & 87 & 88 \\
\hline \multicolumn{11}{|l|}{ Balaenidae } \\
\hline Northern right whale & 3155 & 0.13 & 410 & 0.40 & 0.40 & - & 0.10 & - & - & - \\
\hline Southern right whale & 2900 & 0.10 & 290 & - & - & - & - & 0.60 & 0.40 & - \\
\hline Bowhead whale & 4000 & 0.10 & 400 & 0.80 & 0.20 & - & - & - & - & - \\
\hline Pygmy right whale & 3000 & 0.55 & 1650 & - & - & - & - & 0.60 & 0.40 & - \\
\hline \multicolumn{11}{|l|}{ Eschrichtidae } \\
\hline Gray whale & 21113 & 1.00 & 21113 & 0.40 & 0.50 & - & 0.10 & - & - & - \\
\hline \multicolumn{11}{|l|}{ Balaenopteridae } \\
\hline Fin whale & 115500 & 0.39 & 45045 & 0.11 & 0.04 & 0.19 & 0.27 & 0.16 & 0.17 & 0.06 \\
\hline Blue whale & 14000 & 0.34 & 4760 & 0.11 & 0.04 & 0.19 & 0.27 & 0.16 & 0.17 & 0.06 \\
\hline Minke whale & 860000 & 0.14 & 120400 & 0.11 & 0.04 & 0.19 & 0.27 & 0.16 & 0.17 & 0.06 \\
\hline Sei whale & 39000 & 0.45 & 17550 & 0.11 & 0.04 & 0.19 & 0.27 & 0.16 & 0.17 & 0.06 \\
\hline Bryde's whale & 112000 & 0.86 & 96320 & 0.10 & - & 0.20 & 0.35 & 0.15 & 0.20 & - \\
\hline Humpback whale & 22000 & 0.25 & 5500 & 0.11 & 0.04 & 0.19 & 0.27 & 0.16 & 0.17 & 0.06 \\
\hline \multicolumn{11}{|l|}{ Ziphiidae } \\
\hline Tasman beaked whale & '000 & 0.90 & 2700 & - & - & - & - & 0.50 & 0.50 & - \\
\hline Arnoux's beaked whale & '0 000 & 0.34 & 10200 & - & - & - & - & 0.50 & 0.25 & 0.25 \\
\hline Baird's beaked whale & '0 000 & 1.00 & 30000 & 0.50 & 0.30 & - & 0.20 & - & - & - \\
\hline Longman's beaked whale & '000 & 0.50 & 1500 & - & - & 1.00 & - & - & - & - \\
\hline Blainville's beaked whale & '000 & 0.55 & 1650 & 0.15 & - & 0.20 & 0.35 & 0.10 & 0.20 & - \\
\hline Strap-toothed whale & '000 & 0.34 & 1020 & - & - & - & - & 0.60 & 0.40 & - \\
\hline Hector's beaked whale & '000 & 0.80 & 2400 & - & - & - & 0.10 & 0.70 & 0.20 & - \\
\hline Gray's beaked whale & '000 & 0.40 & 1200 & - & - & - & - & 0.60 & 0.40 & - \\
\hline
\end{tabular}


TABLE 2. (Continued). Global and Pacific population estimates for the 84 species of marine mammals inhabiting the Pacific Ocean during the 1980s and early 1990s. The proportions of animals within the Pacific and within each of the 7 Pacific FAO areas were estimated from range maps displaying the distribution of each species. Population estimates were largely drawn from Northridge (1984), Reijnders et al. (1993) and Jefferson et al. (1993). Order of magnitude estimates are indicated by an apostrophe (e.g. '000).

\begin{tabular}{|c|c|c|c|c|c|c|c|c|c|c|}
\hline \multirow[b]{2}{*}{$\begin{array}{l}\text { Species } \\
\text { common names }\end{array}$} & \multicolumn{3}{|c|}{ Proportion } & \multicolumn{7}{|c|}{ Proportion of Pacific population in each FAO area } \\
\hline & $\begin{array}{l}\text { World } \\
\text { population }\end{array}$ & $\begin{array}{c}\text { in } \\
\text { Pacific }\end{array}$ & $\begin{array}{c}\text { Pacific } \\
\text { population }\end{array}$ & 61 & 67 & 71 & 77 & 81 & 87 & 88 \\
\hline
\end{tabular}

Ziphiidae (continued)

Stejneger's beaked whale Andrews' beaked whale

Ginkgo-toothed beaked whale

Hubb's beaked whale

Pygmy beaked whale

Cuvier's beaked whale

Southern bottlenose whale

\section{Physeteridae}

Sperm whale

Pygmy sperm whale

Dwarf sperm whale

\begin{tabular}{|c|c|c|}
\hline 1900000 & 0.62 & 1178000 \\
\hline '0 000 & 0.55 & 16500 \\
\hline '0 000 & 0.55 & 16500 \\
\hline
\end{tabular}

'000 1.00

'000 0.50

'000 0.95

'000 1.00

'000 1.00

'0 $000 \quad 0.55$

'0 $000 \quad 0.34$

$\begin{array}{rrr}3 & 000 & 0.40 \\ 1 & 500 & - \\ 2 & 850 & 0.10 \\ 3 & 000 & 0.05 \\ 3 & 000 & - \\ 16 & 500 & 0.15 \\ 10 & 200 & -\end{array}$

0.50
-
-
0.40
-
0.10
-

-
0.30
-
-15

0.04

0.05

0.05

0.19
0.20
0.20

0.27

0.30

0.35

0.16

0.15
0.10

0.17

0.20

0.15

\section{Monodontidae}

White whale

\section{Delphinidae}

Rough-toothed dolphin

Indo-Pac. humpbacked dolphin

Irrawaddy dolphin

Melon-headed whale

Pygmy killer whale

False killer whale

Killer whale

Short-finned pilot whale

Dusky dolphin

Hourglass dolphin

Peale's dolphin

Pacific white-sided dolphin

Fraser's dolphin

Bottlenose dolphin

Risso's dolphin

Spinner dolphin

Striped dolphin

Pantropical spotted dolphin

Common dolphin

Southern right whale dolphin

Northern right whale dolphin

Hector's dolphin

Phocoenidae

Harbour porpoise

Vaquita

Burmeister's porpoise

Spectacled porpoise

Dall's porpoise

Finless porpoise

\begin{tabular}{|c|c|c|c|}
\hline 60000 & 0.24 & 14400 & 0.70 \\
\hline '0 000 & 0.60 & 18000 & 0.10 \\
\hline '0 000 & 0.30 & 9000 & 0.10 \\
\hline '0 000 & 0.75 & 22500 & - \\
\hline '0 000 & 0.50 & 15000 & 0.20 \\
\hline '0 000 & 0.50 & 15000 & 0.15 \\
\hline '00 000 & 0.50 & 150000 & 0.10 \\
\hline 80000 & 0.32 & 25600 & 0.11 \\
\hline '00 000 & 0.60 & 180000 & 0.15 \\
\hline '00 000 & 0.65 & 195000 & - \\
\hline '00 000 & 0.34 & 102000 & - \\
\hline '0 000 & 0.30 & 9000 & - \\
\hline 100000 & 1.00 & 100000 & 0.45 \\
\hline '0 000 & 0.40 & 12000 & 0.10 \\
\hline '000 000 & 0.80 & 2400000 & 0.15 \\
\hline '00 000 & 0.60 & 180000 & 0.15 \\
\hline '000 000 & 0.55 & 1650000 & 0.15 \\
\hline '000 000 & 0.55 & 1650000 & 0.15 \\
\hline 000000 & 0.96 & 960000 & 0.15 \\
\hline '000 000 & 0.55 & 1650000 & 0.10 \\
\hline '00 000 & 0.34 & 102000 & - \\
\hline '00 000 & 1.00 & 300000 & 0.45 \\
\hline 5500 & 1.00 & 5500 & - \\
\hline '000 000 & 0.34 & 1020000 & 0.45 \\
\hline 250 & 1.00 & 250 & - \\
\hline '00 000 & 0.60 & 180000 & - \\
\hline '000 & 0.25 & 750 & - \\
\hline 150000 & 1.00 & 1150000 & 0.50 \\
\hline '00000 & 0.30 & 90000 & 0.30 \\
\hline
\end{tabular}

0.30

$0.05 \quad 0.25$

0.85

1.00

0.30

0.25

$0.05 \quad 0.20$

$0.04 \quad 0.19$

$0.05 \quad 0.20$

- $\quad-$

-
-
0.40

$-\quad 0.35$
$-\quad 0.35$

$0.05 \quad 0.20$

$-\quad 0.25$

$0.05 \quad 0.20$

0.25

$0.05 \quad 0.20$

0.35

0.35

0.50

-
-
-
0.40
-

$\begin{array}{rrrr}0.40 & 0.05 & 0.15 & - \\ - & 0.05 & - & - \\ - & - & - & - \\ 0.30 & 0.05 & 0.15 & - \\ 0.40 & 0.05 & 0.15 & - \\ 0.35 & 0.10 & 0.20 & - \\ 0.27 & 0.16 & 0.17 & 0.06 \\ 0.35 & 0.10 & 0.15 & - \\ - & 0.50 & 0.50 & - \\ - & 0.50 & 0.30 & 0.20 \\ - & - & 1.00 & - \\ 0.15 & - & - & - \\ 0.30 & 0.05 & 0.20 & - \\ 0.30 & 0.05 & 0.15 & - \\ 0.25 & 0.15 & 0.20 & - \\ 0.40 & 0.05 & 0.15 & - \\ 0.35 & 0.10 & 0.15 & - \\ 0.40 & 0.05 & 0.15 & - \\ 0.30 & 0.15 & 0.20 & - \\ - & 0.60 & 0.35 & 0.05 \\ 0.20 & - & - & - \\ - & 1.00 & - & - \\ & & & - \\ 0.05 & - & - & - \\ 1.00 & - & - & - \\ - & & 1.00 & - \\ - & 0.70 & 0.30 & - \\ 0.10 & - & - & - \\ - & - & - & - \\ & & & \end{array}$


TABLE 2. (Continued). Global and Pacific population estimates for the 84 species of marine mammals inhabiting the Pacific Ocean during the 1980s and early-1990s. The proportions of animals within the Pacific and within each of the 7 Pacific FAO areas were estimated from range maps displaying the distribution of each species. Population estimates were largely drawn from Northridge (1984), Reijnders et al. (1993) and Jefferson et al. (1993). Order of magnitude estimates are indicated by an apostrophe (e.g. '000).

\begin{tabular}{|c|c|c|c|c|c|c|c|c|c|c|}
\hline \multirow[b]{2}{*}{$\begin{array}{l}\text { Species } \\
\text { common names }\end{array}$} & \multirow{2}{*}{$\begin{array}{c}\text { World } \\
\text { population }\end{array}$} & \multicolumn{2}{|c|}{ Proportion } & \multicolumn{7}{|c|}{ Proportion of Pacific population in each FAO area } \\
\hline & & $\begin{array}{c}\text { in } \\
\text { Pacific }\end{array}$ & $\begin{array}{c}\text { Pacific } \\
\text { population }\end{array}$ & 61 & 67 & 71 & 77 & 81 & 87 & 88 \\
\hline \multicolumn{11}{|l|}{ Otariidae } \\
\hline Steller sea lion & 110000 & 1.00 & 110000 & 0.35 & 0.60 & - & 0.05 & - & - & - \\
\hline California sea lion & 175000 & 1.00 & 175000 & - & 0.20 & - & 0.75 & - & 0.05 & - \\
\hline South American sea lion & 230000 & 0.50 & 115000 & - & - & - & - & - & 1.00 & - \\
\hline Hooker's sea lion & 12000 & 1.00 & 12000 & - & - & - & - & 1.00 & - & - \\
\hline Northern fur seal & 1200000 & 1.00 & 1200000 & 0.40 & 0.55 & - & 0.05 & - & - & - \\
\hline Guadalupe fur seal & 6000 & 1.00 & 6000 & - & - & - & 1.00 & - & - & - \\
\hline Juan Fernandez fur seal & 12000 & 1.00 & 12000 & - & - & - & - & - & 1.00 & - \\
\hline Galapagos fur seal & 40000 & 1.00 & 40000 & - & - & - & - & - & 1.00 & - \\
\hline South American fur seal & 595000 & 0.55 & 327250 & - & - & - & - & 1.00 & 1.00 & - \\
\hline Australian fur seal & 40000 & 0.15 & 6000 & - & - & - & - & 1.00 & - & - \\
\hline New Zealand fur seal & 67000 & 0.60 & 40200 & - & - & - & - & - & - & - \\
\hline \multicolumn{11}{|l|}{ Odobenidae } \\
\hline Walrus & 230000 & 0.80 & 184000 & 0.4 & 0.60 & - & - & - & - & - \\
\hline \multicolumn{11}{|l|}{ Phocidae } \\
\hline Harbour seal & 368000 & 0.60 & 220800 & 0.30 & 0.50 & - & 0.20 & - & - & - \\
\hline Larga seal & 230000 & 1.00 & 230000 & 0.75 & 0.25 & - & - & - & - & - \\
\hline Ringed seal & 6500000 & 0.15 & 975000 & 0.70 & 0.30 & - & - & - & - & - \\
\hline Ribbon seal & 216000 & 1.00 & 216000 & 0.70 & 0.30 & - & - & - & - & - \\
\hline Bearded seal & 800000 & 0.50 & 400000 & 0.65 & 0.35 & - & - & - & - & - \\
\hline Hawaiian monk seal & 1500 & 1.00 & 1500 & 0.10 & - & - & 0.90 & - & - & - \\
\hline Southern elephant seal & 750000 & 0.05 & 37500 & - & - & - & - & 0.45 & 0.25 & 0.30 \\
\hline Northern elephant seal & 125000 & 1.00 & 125000 & 0.15 & 0.75 & - & 0.20 & - & - & - \\
\hline Crabeater seal & 11900000 & 0.11 & 1309000 & - & - & - & - & 0.25 & 0.15 & 0.60 \\
\hline Ross seal & 130000 & 0.50 & 65000 & - & - & - & - & 0.20 & 0.10 & 0.70 \\
\hline Leopard seal & 300000 & 0.33 & 99000 & - & - & - & - & 0.25 & 0.15 & 0.60 \\
\hline Weddell seal & 750000 & 0.33 & 247500 & - & - & - & - & 0.30 & 0.20 & 0.50 \\
\hline \multicolumn{11}{|l|}{ Mustelidae } \\
\hline Sea otter & 150000 & 1.00 & 150000 & 0.40 & 0.50 & - & 0.10 & - & - & - \\
\hline Marine otter & 10000 & 1.00 & 10000 & - & - & - & - & - & 1.00 & - \\
\hline
\end{tabular}

and field measurements. We superimposed these 29 provinces of the Pacific Ocean onto the seven FAO areas in the Pacific Ocean to compute weighted mean estimates of primary production for each FAO area (Table 1).

The primary production $\left(P_{c}\right)$ required to produce the fish caught by commercial fisheries was calculated, based on the $10 \%$ transfer efficiency between trophic levels estimated in Pauly and Christensen (1995), from

$$
P_{c}=\sum_{g=1}^{14} C_{g} 10^{\left(L_{g}-1\right)}
$$

where $C_{g}$ is the catch and $L_{g}$ is the trophic level of 'commodity' group $g$. Trophic levels were adapted from the 48 ECOPATH ecosystem models documented in Pauly and Christensen (1995; see also Christensen and Pauly, 1992a,b; 1993; and Pauly and Christensen, 1993). Trophic levels were calculated for each group from the mean trophic level of 
its prey (weighted by consumption) plus 1, starting from primary producers (mainly planktonic algae) and detritus, both with a definitional trophic level equal to unity. This is illustrated by the trophic representation of FAO Area 77 in Fig. 2 (see Appendix 1 for details). Transfer efficiencies between

TABLE 3. Definition of prey groups and related information required to assess the trophic impact of marine mammals. Examples of diet compositions are shown for 6 of the 84 species of Pacific marine mammals (see Pauly et al., 1997).

\begin{tabular}{|c|c|c|c|c|c|c|c|c|}
\hline Feature/Group & $\begin{array}{c}\text { Benthic } \\
\text { invertebrates }^{a}\end{array}$ & $\begin{array}{c}\text { Large } \\
\text { Zooplankton }^{\mathrm{b}}\end{array}$ & $\begin{array}{l}\text { Small } \\
\text { squids }^{c}\end{array}$ & $\begin{array}{l}\text { Large } \\
\text { squids }\end{array}$ & $\begin{array}{c}\text { Meso- } \\
\text { pelagics }^{\mathrm{e}}\end{array}$ & $\begin{array}{c}\text { Small } \\
\text { pelagics }^{\mathrm{f}}\end{array}$ & $\begin{array}{l}\text { Misc. } \\
\text { fishes }\end{array}$ & $\begin{array}{c}\text { Higher } \\
\text { vertebrates }^{\mathrm{h}}\end{array}$ \\
\hline Trophic levels ${ }^{\mathrm{i}}$ & 2.2 & 2.2 & 3.2 & 3.7 & 2.7 & 3.3 & 3.3 & 4.0 \\
\hline \multicolumn{9}{|l|}{ Diet composition } \\
\hline Southern right whale & - & 1 & - & - & - & - & - & - \\
\hline Gray whale & 0.8 & 0.1 & - & - & - & 0.1 & - & - \\
\hline Longman's beaked whale & - & - & 0.4 & 0.4 & 0.2 & - & - & - \\
\hline Spinner dolphin & - & - & 0.2 & 0.2 & 0.4 & - & 0.2 & - \\
\hline Antarctic fur seal & - & 0.5 & 0.1 & 0.1 & 0.1 & - & 0.2 & - \\
\hline Leopard seal & - & 0.3 & 0.1 & - & - & 0.1 & 0.1 & 0.4 \\
\hline
\end{tabular}

a Echinoderms (sea urchins and some sea stars), molluscs (abalone, bivalves and some octopi) and macrobenthic crustaceans.

b Mainly of crustaceans, notably euphausiaceans (e.g. Krill, Euphausia superba).

c Squids with mantle length of up to $50 \mathrm{~cm}$, e.g. Gonatidae.

d Squids with mantle length of above $50 \mathrm{~cm}$, e.g. Onychoteuthidae.

e Lanternfish (Myctophidae) and other members of the deep scattering layer (DSL) community.

f Anchovies, sardines, mackerels and allied groups.

g Miscellaneous species, predominantly bottom fishes.

h Marine mammals and birds (e.g. penguins), and some turtles.

i The trophic levels are weighted means taken from Table 1 in Pauly and Christensen (1995), except for the higher vertebrates, whose values is taken as the mean trophic level of all Pacific marine mammals species, minus those which feed on higher vertebrates.

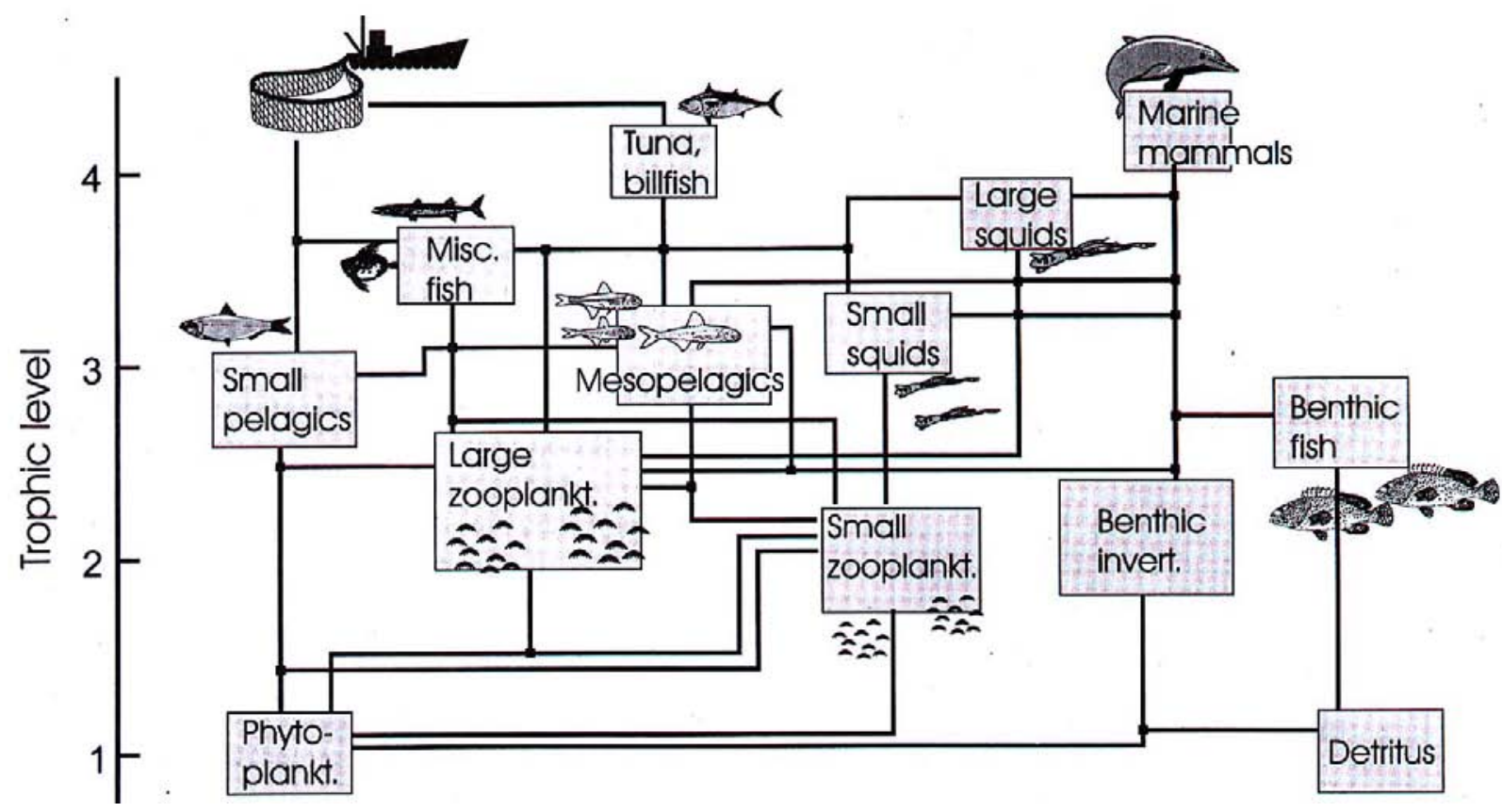

Fig. 2. Trophic model representing the pelagic ecosystem in FAO Area 77 (see Appendix 1 for details). The lines entering the lower half of the boxes indicate consumption flows. Production exits through the upper half of the boxes. Respiration and backflows to the detritius are not shown. Note the difference between those parts and pathways of the system leading to the fisheries, and those leading to the marine mammals. 
trophic levels tend to have a mean value of 0.10 in aquatic ecosystems (Fig. 3; Pauly and Christensen, 1995).

The amount of primary production $\left(P_{i}\right)$ required to produce the prey consumed by marine mammals was estimated from

$$
P_{i}=Q_{i} \sum_{g=1}^{8} d_{i, g} 10^{\left(L_{i, g}-1\right)}
$$

where $Q_{i}$ is the total amount of prey caught in $\mathrm{kg}$ by species $i$ (Equation 1), $d_{i, g}$ is the proportion of their total diet consisting of prey group $g$, and $L_{i, g}$ is the trophic level of the prey group. Diets of the 84 Pacific species of marine mammals were taken from published reports of food and feeding habits, and re-expressed in terms of the 8 prey groups defined in Table 3 (details in Pauly et al., 1997). The few species (mainly Mesoplodon spp.) for which diet composition were not available were assumed to have the same feeding habits as their conspecifics. Trophic levels of marine mammals (see above) were calculated from the trophic level of their prey (in Table 3) and ranged from 4.6 in killer whales to 3.2 in right, blue, fin and bowhead whales (Pauly et al., 1997).

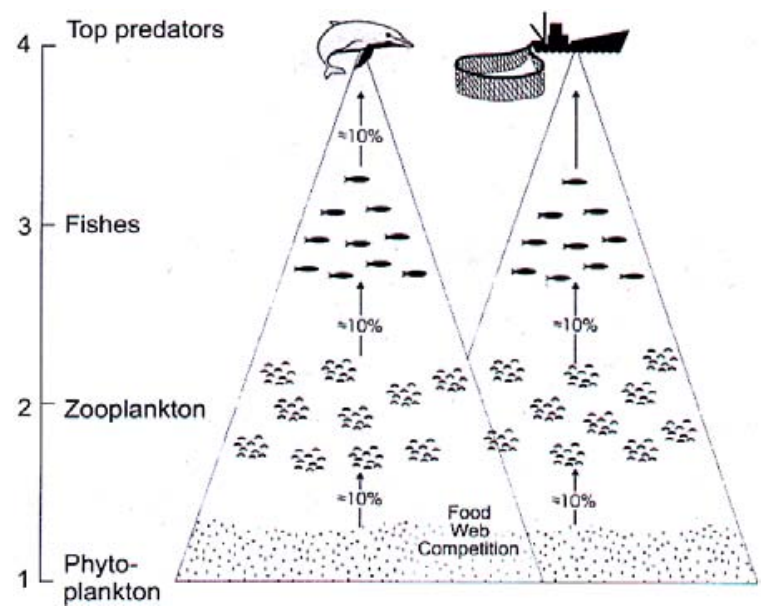

Fig. 3. Schematic representation of 'food web competition', proposed to explain how some groups of top predators, such as marine mammals, may be affected by fisheries even when the prey and catch species do not overlap. Food web competition occurs at the base of the food pyramids, and involves the primary production required to sustain these pyramids.

\section{Resource overlap}

The degree of resource overlap between fisheries and the major groups of marine mammals in each of the seven Pacific FAO areas were calculated using a niche-overlap index modified from MacArthur and Levins (1967) of the form

$$
\alpha_{i, j}=\frac{2 \sum_{k} p_{i, k} p_{j, k}}{\sum_{k}\left(p_{i, k}^{2} p_{j, k}^{2}\right)}
$$

where $\alpha_{i, j}$ (ranging from 0 to 1 ) expresses how species and/or fisheries $i$ and $j$ share the resource $k$, and $p_{i, k}$ and $p_{j, k}$ express the proportions that each of the $k$ resources contributes to the diets or catches (i.e. the amount of primary production required to sustain fisheries - Equation 4, or marine mammals - Equation 5, divided by total available primary production).

The analysis was simplified by aggregating the marine mammals into five groups: baleen whales, beaked whales, dolphins and porpoises, pinnipeds, and all 84 Pacific species of marine mammals combined.

\section{Results and Discussion}

\section{Catch}

The amount of fish caught in the Pacific Ocean rose from 2 million tons in 1948 to over 50 million tons in 1992 (Fig. 1). About 50\% of the total Pacific catch has traditionally come from the mixed stock fisheries off the coasts of Russia, China and Japan (FAO Area 61). Major fisheries have also occurred in Areas 87 (South America) and 71 (Philippines). South American fisheries primarily targeted anchoveta (Engraulis ringens) until their collapse in 1972, and shifted thereafter toward sardines (Sardinops sagax) and horse mackerel (Trachurus murphyi). Elsewhere in the Pacific, catches have been relatively small, and dominated by groundfish in the Gulf of Alaska and Bering Sea, and tuna in the Central Pacific (Fig 1).

Levels of by-catch differed among areas (Alverson et al., 1994), ranging from a low of $18 \%$ of total catch off South America (Area 87) to a high of 50\% in the Central Pacific off the coast of North America (Area 77). Overall, by-catch averaged 34\% of the total 1992 Pacific catch (Table 1). 
Catches have declined in some areas of the $\mathrm{Pa}$ cific and may have peaked in others (Fig. 1). Declining catches in Areas 61 and 77 may be due to overfishing, decreasing fishing effort, or both. Unfortunately, it is difficult to draw firm conclusions when no reliable estimates exist of the level of fleet sizes and effort in the Pacific as a whole. It appears however that the Pacific fisheries cannot continue to expand as they have previously.

\section{Consumption}

Pacific marine mammals, with a total biomass of approximately 25 million tons (over half of which were sperm whales), were estimated to consume about 150 million tons of food per year (Table 3 ), i.e. about three times the nominal catch. Over half of the total biomass can be attributed to sperm whales. The most important prey items for the $\mathrm{Pa}$ cific as a whole were squids ( 26 and 41 million tons for small and large squids, respectively) and mesopelagic fishes (25 million tons). Intermediate amounts of miscellaneous fishes (19 million tons) and small pelagics (17 million tons) were consumed, while benthic invertebrates contributed 3-4 millions tons, and higher vertebrates (marine mammals and birds, mainly penguins) only 0.7 million tons.

\section{Primary production}

The primary production required to sustain marine mammals in each of the FAO Areas varied

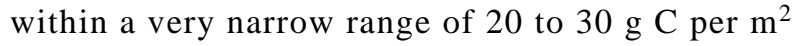
per year (Fig. 4). This consistency between areas suggests that marine mammals may be fully exploiting their marine environments, which may reflect a long evolutionary history that has seen marine mammals adapt their morphology and respiratory

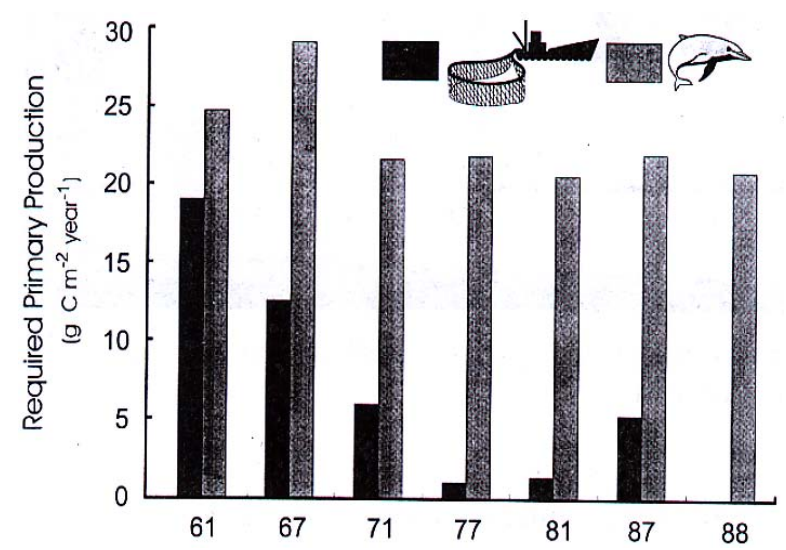

Fig. 4. Primary production required to sustain marine mammals and fisheries in the Pacific ocean, by FAO area. physiology to fully exploit the available feeding niches (e.g. in the deep-scattering-layer). Levels of primary production required to sustain fisheries varies much more between the different areas of the Pacific, depending upon the level of fishing effort and the type of resource exploited (Fig. 4).

\section{Resource competition}

Commercial fisheries target only $35 \%$ of the prey items sought by marine mammals (Fig. 5) - a figure far less than might be expected considering the frequent complaints about marine mammals by some fishers. Over $65 \%$ of the prey consumed by marine mammals are, as a whole, not of current commercial interest. The greatest overlap with fisheries for all areas of the Pacific combined occurs with pinnipeds $(60 \%)$ and dolphins and porpoises $(50 \%)$. The least overlap is with baleen whales and beaked whales (Fig. 5).

Specialized feeding habits further imply that the observed dietary overlap between the prey items of marine mammals and the 'prey' of the fisheries is less than expected. For example, most of the squids and fish which make up such a substantial part of the marine mammal diet are deep-water species not fit for human consumption, nor indeed catchable in commercial quantities using current fishing gear. Similarly, the small fish which make up the mesopelagic community consumed by marine mammals in oceanic areas contain high levels of wax esters (i.e. alkoxydigliceridae) that renders them unfit for human consumption even if their size, appearance and consistency allowed for such (see Gjøsaeter and Kawaguchi, 1980).

The most significant consumer of fish and competitor of commercial fisheries is probably other predatory fish, and not marine mammals. For example, the documented biomass fluxes in the ecosystem model (Fig. 2, Table 4, and Appendix 1) imply that the amount of fish consumed by fish in the Eastern Central Pacific (Table 5) is an order of magnitude higher than the amount consumed by the marine mammals (Christensen, 1996). Thus fish predation should be of greater concern to the fisheries than predation by marine mammals.

Although direct competition between fisheries and marine mammals for prey appears rather limited, indirect competition might occur for the primary production which sustains each of them. As shown in Fig. 3, food web competition occurs when 


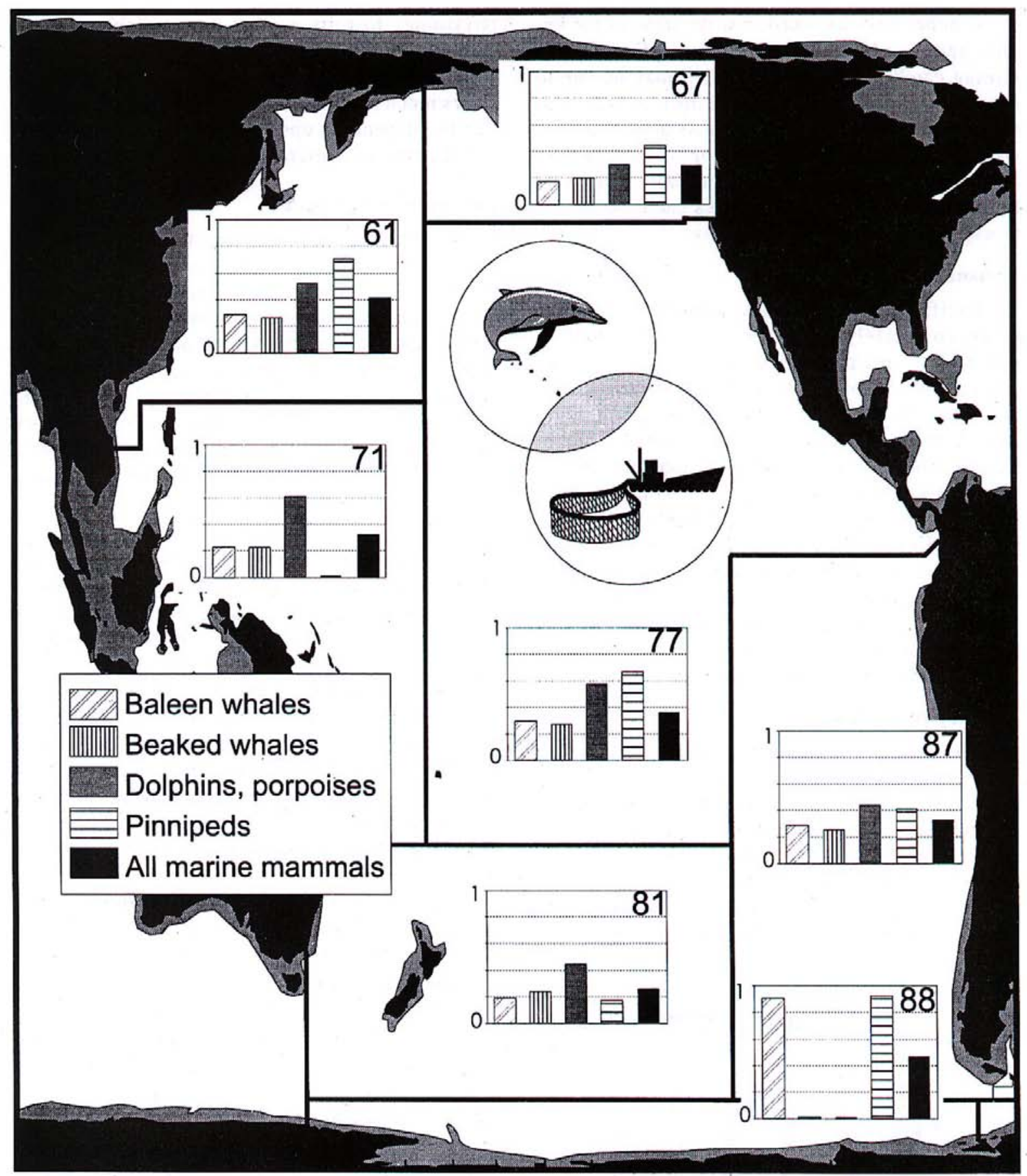

Fig. 5. Overlap between the prey composition of four groups of marine mammals (plus all marine mammals combined) and the catch composition of the fisheries by FAO area.

there is potential overlap of the trophic flows supporting a given group (such as marine mammals) with the trophic flows supporting another group (such as fisheries). The relationship between the size of fishery catches (Table 1) and the amounts of primary production required to sustain fisheries and marine mammals suggests that the primary production available to marine mammals may decline as catches increase (Fig. 6). This raises the possibility that Pacific fisheries in some FAO areas may 
TABLE 4. Food consumption (tons $\times 10^{3}$ per yr) by marine mammals (biomass in tons $\times 10^{6}$ ) in the Pacific Ocean, by FAO area and food type.

\begin{tabular}{|c|c|c|c|c|c|c|c|c|c|c|}
\hline \multirow[b]{2}{*}{$\begin{array}{l}\text { FAO } \\
\text { Area }\end{array}$} & \multirow{2}{*}{$\begin{array}{l}\text { Biomass } \\
\text { marine } \\
\text { mammals }\end{array}$} & \multirow{2}{*}{$\begin{array}{c}\text { Benthic } \\
\text { invertebrates }\end{array}$} & \multirow[b]{2}{*}{$\begin{array}{c}\text { Large } \\
\text { zooplankton }\end{array}$} & \multirow[b]{2}{*}{$\begin{array}{l}\text { Small } \\
\text { squids }\end{array}$} & \multicolumn{2}{|c|}{ Consumption } & \multirow[b]{2}{*}{$\begin{array}{c}\text { Meso- } \\
\text { pelagics }\end{array}$} & \multirow[b]{2}{*}{$\begin{array}{l}\text { Misc. } \\
\text { fishes }\end{array}$} & \multirow[b]{2}{*}{$\begin{array}{c}\text { Higher } \\
\text { vertebrates }\end{array}$} & \multirow[b]{2}{*}{ Total } \\
\hline & & & & & $\begin{array}{l}\text { Large } \\
\text { squids }\end{array}$ & $\begin{array}{c}\text { Small } \\
\text { pelagics }\end{array}$ & & & & \\
\hline 61 & 3.22 & 1568 & 1956 & 3402 & 5043 & 2299 & 3240 & 2770 & 99 & 20378 \\
\hline 67 & 1.35 & 1473 & 681 & 1442 & 2066 & 961 & 1455 & 1170 & 85 & 9334 \\
\hline 71 & 4.61 & 28 & 2853 & 4820 & 7595 & 2994 & 4432 & 3520 & 79 & 26320 \\
\hline 77 & 6.88 & 204 & 4364 & 6989 & 11270 & 4351 & 6828 & 4972 & 131 & 39108 \\
\hline 81 & 3.88 & 57 & 3190 & 3680 & 6261 & 2368 & 3660 & 2421 & 92 & 21729 \\
\hline 87 & 4.23 & 168 & 3199 & 4267 & 6891 & 2787 & 4037 & 3095 & 130 & 24573 \\
\hline 88 & 1.49 & 55 & 2548 & 1332 & 2219 & 980 & 1161 & 883 & 108 & 9286 \\
\hline Total & 25.67 & 3552 & 18791 & 25931 & 41345 & 16741 & 24814 & 18831 & 723 & 150728 \\
\hline
\end{tabular}

TABLE 5. Estimates ( $\mathrm{g}$ per $\mathrm{m}^{2}$ per $\mathrm{yr}$ ) of fish consumed by fish, marine mammals or caught by fisheries in 1992 the Eastern Central Pacific (FAO Area 77). Estimated from the Ecopath trophic model in Fig. 2 and Appendix 1.

\begin{tabular}{lccccc}
\hline \hline & & \multicolumn{2}{c}{ Prey } \\
Predator & Tuna, billfish & Miscellaneous fish & Mesopelagics & Benthic fish & Small pelagics \\
\hline Fishery & 0.01 & 0.01 & 0.00 & 0.00 & 0.01 \\
Marine mammals & 0.00 & 0.10 & 0.14 & 0.00 & 0.09 \\
Fish & 0.00 & 0.23 & 0.55 & 0.07 & 2.09 \\
\hline
\end{tabular}

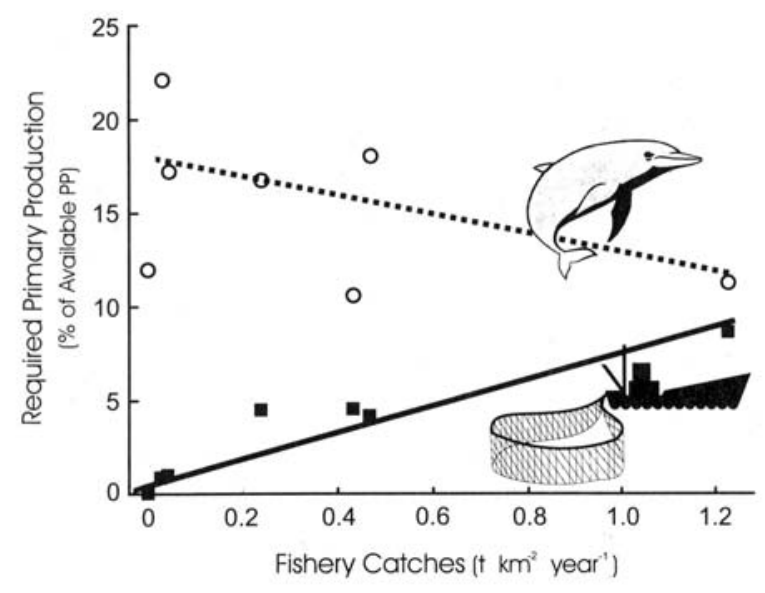

Fig. 6. Primary production requirements relative to fishery catches. Primary production required by the marine mammals of the Pacific ocean is low where fisheries catches (and hence the primary production required by the fisheries) is high. This may indicate food web competition as defined in Fig. 3. have entered into 'food web competition' with marine mammals.

\section{Management and research implications}

Catches by the Russian Federation, both in the Pacific and elsewhere, have decreased since the breakdown of the USSR, which along with the world-wide introduction of 200 nautical mile exclusive economic zones caused the demise of the subsidized, long-distance Soviet fishery. However, the best global estimates show that the fishing fleets elsewhere have more than compensated for this decrease (FAO, 1995). While proofs are lacking in the Pacific, the trend is clear: the excessive build up, and overcapitalization in the fishing fleets leads unavoidably to overfishing, and potentially threatens marine mammals with food web competition.

We wish to stress that our results are tentative and will be refined as better estimates of diets, abundance and biomass become available. As a whole, our study implies an uncertain future for 
fisheries and marine mammals in the Pacific Ocean, and will need further investigation and testing by extension to the Atlantic and Indian Oceans. It is clear, however, that the Pacific fisheries cannot continue to expand as they have previously.

\section{Acknowledgments}

We are grateful for the assistance of Merly Medina, and Sandra Gayosa for the preparation of the text, and Cris Bunao (all from ICLARM) for the graphs. AWT was supported in part by the North Pacific Marine Science Foundation through the North Pacific Universities Marine Mammal Research Consortium.

\section{References}

ALVERSON, D. L., M. H. FREEBERG, S. A. MURAWSI, and J. A. POPE. 1994. A global assessment of fisheries bycatch and discards. FAO Fish. Tech. Pap., 339: 233 p.

BARLOW, J. and P. BOVENG. 1991. Modeling age-specific mortality for marine mammal populations. Mar. Mam. Sci., 7: 50-65.

BLACKBURN, M. 1981. Low latitude gyral regions. In: Analysis of marine ecosystems. A. R. Longhurst (ed). Academic Press, San Diego, p. 3-29.

BONNER, W. N. 1989. Whales of the world. Fact on File, New York, $192 \mathrm{p}$.

CHRISTENSEN, V. 1996. Managing fisheries involving predator and prey species. Rev. Fish Biol. Fish., 6: $1-26$.

CHRISTENSEN, V. and D. PAULY. 1992a. A guide to the ECOPATH II software system (version 2.1). ICLARM Software 6, 72 p. International Center for Living Aquatic Resources Management (ICLARM), Manila.

CHRISTENSEN, V. and D. PAULY. 1992b. The ECOPATH II - a software for balancing steady-state ecosystem models and calculating network characteristics. Ecological Modelling, 61: 169-185.

CHRISTENSEN, V. and D. PAULY (eds.). 1993. Trophic models of aquatic ecosystems. ICLARM Conf. Proc. 26, $390 \mathrm{p}$.

FAO. 1994. FISHSTAT-PC-Data retrieval, graphical and analytical software for microcomputers. FAO, Rome.

1995. The state of world fisheries and aquaculture. Rome, $57 \mathrm{p}$.

GJØSAETER, J., and K. KAWAGUCHI. 1980. A review of world resources of mesopelagic fishes. FAO Fish. Tech. Pap., 193: 151 p.

HOPKINS, T. L. and R. C. BAIRD. 1977. Aspects of the feeding ecology of oceanic midwater fishes. In: Oceanic sound scattering prediction. N. R. Andersen and B. J. Zaruranec (eds). Plenum Press, New York, p. 325-360.
INNES, S., D. M. LAVIGNE, W. M. EARLE and K. M. KOVACS. 1987. Feeding rates of seals and whales. J. Anim. Ecol., 56: 115-130.

JEFFERSON, T. A., S. LEATHERWOOD and M. A. WOBBER. 1993. Marine mammals of the world. FAO Species Identification Guide. Rome, 320 p.

KLINOWSKA, M. (ed.). 1991. Dolphin, porpoises and whales of the world. The IUCN Red Data Book. The World Conservation Union, Gland and Cambridge, 429 p.

LONGHURST, A., S. SATHYENDRANATH, T. PLATT and C. CAVERHILL. 1995. An estimate of global primary production in the ocean from satellite radiometer data. J. of Plank. Res., 17: 1245-1271.

MacARTHUR, R. H. and R. LEVINS. 1967. The limiting similarity, convergence and divergence of coexisting species. Am. Nat., 101: 377-385.

MANN, K. 1984. Fish production in open ocean ecosystems. In: Flows of energy and materials in marine ecosystems. M. J. R. Fasham (ed.). Plenum Press, New York, p. 435-458.

MENASVETA, D. 1980. Resources and fisheries of the Gulf of Thailand. SEAFDEC Text/Reference Book Ser. No. 8: 108 p.

NORTHRIDGE, S. P. 1984. World review of interactions between marine mammals and fisheries. FAO Fish. Tech. Pap., 251: 190 p.

OLSON, R. J. and C. H. BOGGS. 1986. Apex predation by yellowfin tuna (Thunnus albacares): independent estimates from gastric evacuation and stomach contents, bioenergetics, and cesium concentrations. Can. J. Fish. Aquat. Sci., 43: 1760-1775.

PAULY, D. 1989. Food consumption by tropical and temperate fish populations: some generalizations. J. Fish. Biol., 35 (Suppl. A): 11-20.

PAULY, D. and V. CHRISTENSEN. 1993. Stratified models of large marine ecosystems: a general approach and an application to the South China Sea. In: Large marine ecosystems: stress, mitigation and sustainability. K. Sherman, L. M. Alexander and B. D. Gold (eds.). AAAS Publication, Washington, D.C., p. 148-174.

PAULY, D. and V. CHRISTENSEN. 1995. Primary production required to sustain global fisheries. Nature, 374: 255-257.

PAULY, D., V. SAMBILAY, Jr. and S. OPITZ. 1993. Estimates of relative food consumption by fish and invertebrate populations, required for modelling the Bolinao reef ecosystem, Philippines. In: Trophic Models of Aquatic Ecosystems. V. Christensen and D. Pauly (eds.) ICLARM Conference Proceedings, No. 26, p. 236-251.

PAULY, D., A. W. TRITES, E. CAPUli and V. CHRISTENSEN. 1997. Diet composition and trophic levels of marine mammals. ICES J. Mar. Sci., (in press).

PETERS, A. 1983. The New Cartography. Friendship Press, New York, 163 p. 
REIJNDERS, P., S. BRASSEUR, J. VAN DER TOORN, P. VAN DER WOLF, I. BOYD, J. HARWOOD, D. LAVIGNE, and L. LOWRY. 1993. Seals, fur seals, sea lions, and walrus. Status survey and conservation action plan. IUCN/SSC Specialist Group, IUCN, Gland, Switzerland.

ROPER, C. F. E., M. J. SWEENEY and C. E. NAUEN. 1984. Cephalopods of the World: an annotated and illustrated catalogue of species of interest to fisheries. FAO Species Synopsis, 125, Vol. 3: 277 p.

TANDOG-EDRALIN, D. D., E. C. CORTESZARAGOZA, P. DALZELL and D. PAULY. 1990. Some aspects of the biology of skipjack (Katsuwonus pelamis) in Philippine waters. Asian Mar. Biol.,
7: $15-29$.

TRITES, A. W. and D. PAULY. 1997. Estimates of mean body weights for marine mammals from measurements of maximum body lengths. Can. J. Zool., in press.

YAMASHITA, Y., N. PIAMTHIPMANUS and $\mathrm{K}$. MOCHIUZUKI. 1987. Gut contents analysis of fishes sampled from the Gulf of Thailand. In: Studies on the mechanism of marine productivity in the shallow waters around the South China Sea, with special reference to the Gulf of Thailand. K. Kawagushi (ed.). Grant-in-Aid No. 61043019 for Overseas Scientific Survey, Ministry of Education, Science and Culture of Japan, Tokyo, p. 33-35. 


\section{APPENDIX 1. Construction of a model of trophic interaction in FAO Area 77 (Eastern Central Pacific).}

To illustrate the method for construction of balanced trophic flow models, an ecosystem model was constructed for the Eastern Central Pacific (FAO area 77) using the Ecopath software (Christensen and Pauly, 1992a, b). The model was based on published information, supplemented by various approximations. A number of the estimates used are discussed by Pauly and Christensen (1993). The description below assumes a basic knowledge of the structure of Ecopath, and of the parameters required.

Catches are based on the FAO statistics for Area 77 in 1992 (FAO, 1994). The model included a total of 12 living groups, plus a detritus group:

1. Marine mammal biomass (B) and consumption/biomass ratio $(\mathrm{Q} / \mathrm{B})$ were estimated as described in the text above. The production/biomass ratio (P/B) was assumed to be 0.1 per year, implying an average longevity of about 10 years. Diet composition was obtained as a weighted average of the diet composition of all species of marine mammals reported from Area 77.

2. Tuna and billfishes. Biomass of these top predators among fishes was estimated as approximately $0.05 \mathrm{~g} \mathrm{~m}^{2}$, while the $\mathrm{P} / \mathrm{B}$ ratio was set at 1.2 per $\mathrm{yr}$, and the $\mathrm{Q} / \mathrm{B}$ at $15 \mathrm{per} \mathrm{yr}$, based on Olson and Boggs (1986). Diet composition was based on information for skipjack (Tandog-Edralin et al. 1990) and yellowfin tuna (Olson and Boggs 1986).

3. Miscellaneous fish. Biomass was assumed to be $0.5 \mathrm{~g}$ per $\mathrm{m}^{2}$, as suggested by Mann (1984) for epipelagic nekton in oceanic areas. Mann (1984) also estimated that the production of epipelagic nekton ranged from 0.5 to $1.3 \mathrm{~g}$ per $\mathrm{m}^{2}$ per yr, yielding P/B values ranging from 1.0-2.6 per yr. We adopted a value of $2.0 \mathrm{yr}$, and assumed $\mathrm{Q} / \mathrm{B}=9.3 \mathrm{per} \mathrm{yr}$ as in for mackerel. (Pauly and Christensen, 1993) Diet composition was based largely on information in Menasveta (1980) and Yamashita et al. (1987).

4. Mesopelagics include myctophids, gonostomatids and sternoptychids. They occur between 200 and $1000 \mathrm{~m}$ during daytime and rise into the upper $200 \mathrm{~m}$ (epipelagic zone) at night to feed primarily on zooplankton. Biomass was assumed to be $2.6 \mathrm{~g}$ per $\mathrm{m}^{2}$ based on data in Gjøsaeter and Kawaguchi (1980) for the western central Pacific. Similarly, estimates of mesopelagic biomass were calculated by Mann (1984) to range from 1.75 to $3.0 \mathrm{~g} \mathrm{per}^{2}$ per yr. Following Mann (1984), we used a Q/B value of 2.9 per year, and a P/B ratio of 0.6 per yr. We followed Hopkins and Baird (1977), who found that more than $70 \%$ by volume of the diet of mesopelagics consisted of crustaceans.

5. Small pelagics include fish such as herrings, sardines and anchovies. Their Q/B ratio was adapted from Pauly (1989), while P/B was estimated from an assumed gross food conversion efficiency (P/Q) of 0.15. Biomass was estimated by the Ecopath software, based on an assumed ecotrophic efficiency of 0.80 , i.e. $80 \%$ of the production of small pelagics was assumed to be caught by the fishery or consumed by predators. The diet of small pelagics was as described by Menasveta (1980) and Yamashita et al. (1987).

6.-7. Small and large squids were those with mantle length smaller and larger than $50 \mathrm{~cm}$, respectively. The catches of small squids were assumed to be $2 / 3$ of the total catch of squids in the area. The $Q / B$ for small squids were based on Pauly et al. (1993), while the Q/B for the larger squids was assumed to be half that of the smaller squids. The P/B was estimated based on assumed gross food conversion efficiencies of 0.20 , and 0.10 for small and large squids, respectively. Biomasses for both groups was estimated using an assumed ecotrophic efficiency of 0.80 . Diet compositions were based on data in Roper et al. (1984).

8. Benthic fish are those living in the deep sea. Mann (1984) gave biomass estimates for the group as a whole ranging from 1.-2. g per $\mathrm{m}^{2}$. We therefore used $1.5 \mathrm{~g}$ per $\mathrm{m}^{2}$. Their P/B was given by Mann (1984) as 0.05 to 0.10 per yr, and we used 0.075 per $\mathrm{yr}$. The $Q / B$ value was estimated from an assumed gross food conversion efficiency of 0.25 , while the dietary composition was based on information given by Mann (1984). 
9. Large zooplankton such as copepods, euphausiids, and decapods had an estimated biomass of $10 \mathrm{~g}$ per $\mathrm{m}^{2}$, and a P/B of 0.5 per yr (Blackburn, 1981). Based on an assumed gross food conversion efficiency of $0.2, \mathrm{Q} / \mathrm{B}$ was estimated as 2.5 per yr.

10. Small or micro-zooplankton were assumed to have a biomass equal to about $25 \%$ of the biomass of large zooplankton (Blackburn, 1981). Their P/B and Q/B ratios were adjusted to account for their smaller sizes.

11. Benthic invertebrates (amphipods, shrimps, and other decapods). Mann (1984) gives a mean biomass of $5.0 \mathrm{~g}$ per $\mathrm{m}^{2}$, and a P/B estimate of 0.1 per yr. With an assumed gross conversion efficiency of 0.25 , Q/B was 0.4 per yr. A diet composition was input which led to mass-balance, given the constraints in $1-12$.

12. Phytoplankton. The primary production was derived as explained in the text.

13. Detritus. This includes all dead material, egesta, excreta and dead organisms.

The model resulting from these estimates and assumption (Fig. 2) is tentative, and is presented here as a possible scenario. Interested readers may obtain further details (including the complete file and the Ecopath software to run it) from Daniel Pauly or Villy Christensen. The latest (Windows 3.1) version of Ecopath includes a Monte-Carlo simulation routine allowing verification, in a Bayesian context, of assumptions such as those presented above. 